\title{
Providing Conditions for Creative Personality Development in the Russian Federation
}

\author{
Elena Blagireva ${ }^{1, *}$ \\ ${ }^{1}$ Russian State Specialized Academy of Arts, Moscow, Russia \\ *Corresponding author. Email: blagireva@list.ru
}

\begin{abstract}
The present article outlines the approaches to ensuing active engagement in the cultural life and harmonious personality development of people with disabilities as strategic resource for the socio-economic development of the country. The author emphasizes the role of society in accumulating cultural capital, and describes the potential of culture and arts institutions in introducing inclusive education in the field of culture and raising the awareness of inclusion among the multicultural society.
\end{abstract}

Keywords: Accessibility of cultural benefits for people with disabilities, Inclusive Practices in culture, Personality development.

\section{INTRODUCTION}

The concept of inclusion has become a common subject of research in the modern society. Inclusion is regarded as "a principle of the social welfare state ... in the context of post-industrial society, associated with the development of the service and information sector, new types of resources, and modification of the social structure". [1]

The relevance of the research subject is justified by the necessity to find modern grounds for studying engagement of disabled people in the cultural life of society. This search is conditioned by the interdisciplinary nature of the concept of inclusion, the constantly changing external environment, and its increasingly complex connections, diversity of ideas, practices, values and priorities. Inclusion goes far beyond pedagogy, social issues, health care, and culture; it is becoming a general humanitarian issue of the $21 \mathrm{st}$ century that covers cultural, social, psychological, economic, information and other aspects of life of the individual and society.

Harmonious personality development and ensuring equal access to cultural benefits are priority tasks of the state. People with disabilities are a valuable resource for socio-cultural and socioeconomic development of the country, so it is important to provide the conditions for them to unleash their creative potential.

According to the Federal Registry of Disabled Persons, the total number of disabled people in the Russian Federation as at January 1, 2021 was 11.6 million; the number of disabled children was 704 thousand. [2]

The issue of social engagement and integration of people with disabilities into the cultural life of society requires thorough research and attention from the government authorities, civil society and business.

The cultural norm of the development of people with disabilities implies ensuring their right to equal access to cultural benefits and participation in creative activities that motivate their inner reserves, including creative ones.

Inclusive creative practices and engagement in theatre, musical, and artistic activity allow unleashing creative potential of an individual and provide a different worldview, full of meaning and high values. Meanwhile, a significant aspect of rehabilitation of people with disabilities is cooperation with physically healthy people. This contributes to the establishment of a cultural norm to treat disabled people as individuals, and recognize their achievements and value for the entire community. 
Nowadays, special attention is given to the issues of accessibility of cultural benefits for people with disabilities. Understanding inclusive creative practices as a resource for successful social transformations requires upgrading the existing models and developing new mechanisms for the implementation of cultural policy aimed at achieving goals in the field of culture through the best possible rationalization of the cultural capital in current social conditions. Therefore, the instruments for achieving these goals assume an important role. It is essential to establish conditions for creativity and self-development of individuals, exercise of human rights in culture, ensuring access to cultural benefits, and enhancing the quality of life in the Russian Federation in general.

Ensuring equal rights and opportunities implies not only implementation of the right of disables people to access cultural benefits, but also the right to participate in the socio-economic development of the country. It is not only accessible social services that contribute to social integration of all members of society, but also the operation of institutions that ensure inclusion of people with disabilities in the cultural life of society and prove the economic feasibility of investment in training and employment of people with disabilities. The prominent ones are cultural and artistic institutions that encourage creative development of young talented people with disabilities and removal of barriers to their personal fulfilment.

\section{ESTABLISHMENT OF THE INCLUSIVE CULTURE}

Linguistically, the concept of inclusion is understood as a process of real inclusion of people with disabilities into active social life.

In the academic literature, different collocations with the word "inclusion" are encountered: sociocultural inclusion, culture of inclusion, inclusive culture, etc. [3] In pedagogy, inclusive culture is most often considered the most important component of inclusive education. According to the Federal Law "On Education in the Russian Federation", it is aimed at "providing equal access to education for all students, with the account of diversity of special educational needs and individual capacities". [4]

Currently in the Russian Federation, there are 5,075 educational institutions in the sector of culture educating 10,747 students with disabilities, which constitutes $0.6 \%$ of the total number of students $(1,781,577$ people).

Over the past five years, the proportion of students with disabilities has remained and constitutes $0.7 \%$ in all levels of education. High enrolment rates of students with disabilities have been observed in $5 \%$ of higher education institutions in the industry.

E.L. Tikhomirova and E.V. Shadrova understand the culture of inclusion as "a special system of relations between all subjects of the educational process (authorities, teaching staff, students, their parents, social partners, etc.) operating based on values and principles of inclusion which are commonly accepted and allow effective interaction in conditions of diversity in order to fulfil the mission of an educational institution". [5]

Currently, there is another, more extended perception of inclusion as "a characteristic feature of everyday practices, expressed in employees' professional competencies, social services, everyday interaction with the community and clients, and the discourse of projects and programmes". [6]

This definition clearly demonstrates an orientation towards the idea of an inclusive society, aimed at "changing society and its institutions so that they are conducive to inclusion" [7], and ensure equal rights and interests of all members of society through services and benefits.

However, inclusion is not just a process of engagement of people with disabilities in the society, their social adjustment and personal fulfilment; it is understanding of the importance of their inclusion in the society and the system of public attitudes towards them that provides equal opportunities for disabled people in a barrier-free environment. [3]

Studying the inclusion indices, British researchers Tony Booth and Mel Ainscow identified three interconnected dimensions necessary for the development of inclusion, which according to the authors, establish transformation of attitudes towards people with disabilities:

- 1) producing inclusive policies (legal frameworks that regulate the process of inclusion and provision of accessible environment);

- 2) evolving inclusive practices (based on well-conceived programme and 
methodological groundworks for the process of inclusion and technologies for its implementation);

- 3) creating inclusive culture, strengthening and promoting its principles and values: implementation of human rights, openness towards cultural diversity, interaction and intercultural dialogue. [8]

In fact, these three dimensions form the basis of socio-cultural inclusion, which incorporates sociocultural, psychological, political, and economic aspects into the overall system. It should be emphasized that in this three-dimensional model, the inclusive culture is an assessment of a society's level of development, expressed in a system of relations, values and benchmarks.

Analysing socio-cultural inclusion in the context of humanization of society, with the increasing role of social responsibility and recognition of the value of other people in society, N.E Sudakova focuses on cultural interaction of the individual and society. [9] As a result of this interaction, the number of unique cultural practices (educational, business, socio-cultural, etc.) available for people with disabilities is increasing.

Therefore, socio-cultural inclusion, which is becoming an imperative, contributes to establishing a new worldview that consists in searching one's own creative nature, and the joy of creation found in creativity and reproduction of creative products and the "capital of diversity".

Currently, the phenomenon of socio-cultural inclusion requires rethinking, taking into consideration rehabilitation practices that focus on inclusion in society and gaining access to cultural benefits and the right to participate creatively in the socio-economic development of society.

\section{ACCESSIBILITY OF SERVICES IN THE RUSSIAN FEDERATION}

According to the UN Convention on the Rights of Persons with Disabilities ratified by the Russian Federation, the laws and regulations of the Russian Federation, Decrees of the President of the Russian Federation and the Ministry of Culture of Russia, under the coordination of the Commission on Disabilities, measures are being taken to provide regular support for inclusive creative projects and ensure the accessibility of cultural benefits for people with disabilities in the Russian Federation.
The priority task is ensuring access to cultural benefits for everyone and providing opportunities to fulfil creative potential.

Over the past three years in the Russian Federation [10]:

- the number of cultural events with the participation of people with disabilities (including online) has increased by 3.5 times (in 2020 - 2,463,986 events; in 2017 - 702,403 events);

- the number of inclusive creative events accessible for people with disabilities organized by institutions of culture has increased by 1.8 times (in $2020-1,447,108$ events; in 2017 - 831,064 events).

The federal projects "Cultural Environment", "Digital Culture", and "Creative People", which are part of the national project "Culture", include measures to be implemented in order to create conditions for disabled people's participation in the cultural life of society and their introduction to cultural values and benefits. The relevant information about the upcoming inclusive events can be found at the "PRO.Kultura.RF" portal of the Ministry of Culture of Russia. In 2020, there were over 68 thousand announcements about events accessible to people with disabilities (out of 330 thousand announcements).

Among the most prominent inclusive creative projects popular with disabled people are the following:

- $\quad$ "Accessible Museum" by the Pushkin State Museum of Fine Arts;

- $\quad$ "The Past at Your Fingertips" by the State Hermitage Museum and the K.K. Grot Boarding School, for visually impaired children;

- "Step towards!" International creative festival for children with disabilities;

- International Charity Festival "White Cane", etc.

Most creative events available for people with disabilities take place in Moscow, St. Petersburg, the Republic of Tatarstan, Novosibirsk Oblast, Kursk Oblast, Nizhny Novgorod Oblast, Sverdlovsk Oblast and Moscow Oblast.

Museums focus on adapting the museum space for people with disabilities (museum tours with video- and audio guides; tactile museum exhibits accessible to visually impaired people; attracting 
Russian sign language interpreters for hearingimpaired people).

Theatre institutions regularly stage inclusive performances (the play "In Touch" staged by the State Theatre of Nations in cooperation with the Deafblind support foundation "Con-nection", included in the UNESCO list of inclusive projects).

Libraries organize book exhibitions, lectures and workshops for a wide audience, including people with disabilities, children with disabilities in particular.

Over the past five years, a regulatory legal framework has been developed (28 orders of the Ministry of Culture, over 500 regional and 1,000 municipal laws and regulations) in order to ensure the accessibility of cultural benefits for people with disabilities.

The Ministry of Culture has developed and submitted to the Government of the Russian Federation a draft federal law "On Amending Article 52 of the Law of the Russian Federation "The Fundamentals of Legislation of the Russian Federation on Culture". It enables cultural institutions to provide benefits for persons, accompanying the Group I and II disabled people to paid events. (sub-section "m", section 2 of the list of instructions of the President of the Russian Federation No. Pr-2243, dated December 31, 2021).

In cooperation with the Ministry of Labour and Social Protection of the Russian Federation, the draft federal law "On Amendments to Legislative Acts of the Russian Federation on the Issues of Comprehensive Habilitation and Rehabilitation of Persons with Disabilities" is being developed. The standard for service provision for socio-cultural habilitation and rehabilitation of people with disabilities, including children with disabilities, is aimed at engaging them in the cultural life of society, ensuring positive lifestyle changes by means of fulfilment of their individual creative potential.

Institutions of culture are working on providing the necessary conditions, both infrastructural and substantive (the quality of services), and monitoring the quality of service provision. The main task to be performed is to improve the life quality of people with disabilities, including children with disabilities, by means of culture.

Recently, there have appeared new formats to engage people with disabilities, including children with disabilities, in the cultural life of society, in particular, the establishment of a network of inclusive creative laboratories. This will provide extra opportunities for communication for talented people with disabilities, social adjustment and promotion of their creative ideas through inclusive practices.

A typical laboratory should:

- provide conditions for ensuring accessibility of facilities and services for people with disabilities;

- employ qualified specialists who have received training in inclusion in the field of culture and arts;

- implement creative initiatives and events in music, theatre, visual and other types of arts.

The institutions of culture of the Russian Federation to house inclusive laboratories will be selected in 2021-2022. They will provide methodological support for other cultural institutions regarding working with people with disabilities, including personnel training and replication of best inclusive practices targeted at talented children and youth with disabilities.

In addition, the priority tasks aimed at sociocultural habilitation and rehabilitation of people with disabilities, including children with disabilities, are as follows:

- developing and adopting the programme for identification of people with disabilities and providing them assistance in the field of culture;

- monitoring and analysing regional inclusive events and projects in the field of culture and arts;

- ensuring replication of best practices of the constituent entities of the Russian Federation in engaging people with disabilities in the cultural life of society.

\section{CONCLUSION}

In the modern world, socio-cultural inclusion is an assessment of a society's degree of civilization, which indicates not so much technological or information and communication transformations of the picture of the world, as changes in the worldview and cultural inclusive practices.

Further research into accessibility and quality of services in the sector of culture and arts, including inclusive projects, will allow realizing the potential of cultural diversity in cultural institutions and 
proving economic viability of investing in career opportunities for students of creative disciplines with disabilities.

\section{AUTHORS' CONTRIBUTIONS}

This article is independently completed by Elena Blagireva.

\section{REFERENCES}

[1] Sigal N.G. Inclusion today: pros and cons: Monograph. Kazan, 2017. 200 p.

[2] The Federal Registry of Disabled Persons. Available at: https://sfri.ru/analitika/chislennost/chislennost ?territory=1(Access date: April 19, 2021).

[3] Antonova V.K. The concepts of social inclusion and exclusion in global society: a journey within social institutions, actors and practices. Journal of Social Policy Research. 2013. V.11. No. 2. Pp. 151-170.

[4] Federal Law No. 273-FZ "On education in the Russian Federation", dated December 29, 2012. Available at: http://consultant.ru/document/cons_doc_law_ 140174

[5] Tikhomirova E.L., Shadrova E.V. On the essence of the concept of inclusive culture. Pedagogy and psychology as a resource for the development of modern society: Proceedings of the IX International conference. Ryazan, 2017. Pp. 93-98.

[6] Yarskaya V.N., Yarskaya-Smirnova E.R. Inclusive culture of social services. Sociological research. 2015. No. 12. Pp. 133140.

[7] Shemanov A.Yu., Popova N.T. Inclusion in a cultural perspective. Psychological Science and Education. 2011. No. 1. Pp. 74-82.

[8] Booth T., Ainscow M. Inclusion Index: A Practical Guide. Translated into Russian by $\mathrm{M}$. Perfilieva. Moscow, 2013. 123 p.

[9] Sudakova N.E. Inclusion as a value core of the philosophy of humanism. Observatory of Culture. 2018. Vol.15. No. 1. Pp. 21-31.

[10] Yakupov A.N., Blagireva E.N. Accessibility of cultural benefits for people with disabilities in the Russian Federation in 2020: Scientific research. Moscow, 2021. 546 p.

[11] State Program of the Russian Federation "Accessible Environment" for 2011-2020. Available at: https://rosmintrud.ru/ministry/programms/3/0

[12] Culture and market. Trusted goods. Ed. by A.A. Rubinshtein, V.Yu. Muzychuk. St. Petersburg, 2013. 400 p.

[13] Sinetskiy S.B. Cultural Politics of the 21st Century: From History to the Project of the Future: Monograph. Chelyabinsk, 2011. 288 p.

[14] Promotion of employment of graduates with disabilities in the field of culture. The website of the Ministry of Culture of the Russian Federation: a database of vacancies. Available at: https://www.mkrf.ru/press/news/vacancy

[15] Shevlyagin A.A. Cultural inclusion in museum. Bulletin of the St. Petersburg Institute of Culture. 2019. No. 1 (38). Pp. 145149.

[16] Bennett T., Deluca D., Bruns D. Putting Inclusion into Practice: Perspectives of Teachers and Parents. Exceptional Children. 1997. Vol. 64, No. 1. P. 115-131.

[17] Giddens A. The Third Way and Its Critics. Cambridge: Policy Press, 2013. 198 p.

[18] THE INCREDIBLE SHRINKING WORLD OF ERIC DREXLER. Available at: http://www.redherring.com/mag/issue22/worl d.html. 